vda, že vzhl'adom k veku už jeho hlas v „štúdiách fašizmu“ nie je tak silný, ako býval, a niekol'ko rokov nič prevratné nepublikoval.

Kniha Fascism without borders: Transnational Connections and Cooperation between Movements and Regimes in Europe, 1918-1945 tak nevyšla z tieňa „obyčajných“ konferenčných zborníkov, ktoré sa kvôli systému hodnotenia publikácií tvária ako kolektívne monografie. Napriek všetkej snahe editorov napísat’ „všeobjímajúci“ úvod, ktorý by dal knihe koncepciu, ide len o súhrn príspevkov rôznej kvality k náhodným témam, ktoré sa nejakým spôsobom dotýkajú problematiky medzinárodnej a cezhraničnej spolupráce fašistických či antifašistických hnutí. Napriek tomu túto publikáciu netreba zatracovat'. Ide o jednu z prvých prác v oblasti, na ktorú sa väčšina „,fašistológov“ momentálne začína sústred’ovat’ a ktorá bude bezpochyby „horúcou témou“ budúceho výskumu fašizmu. Priniesla niekol'ko zaujímavých a podnetných pohl'adov a svojím spôsobom naznačila smer, akým sa historiografia v tejto špecifickej oblasti môže d'alej vyvíjat'.

Jakub Drábik

Historický ústav SAV

\title{
CHODĚJOVSKÝ, Jan (Ed.). PAŘÍŽ 1919. Mírová konference očima poradců československé a polské delegace. Praha: Nakladatelství Lidové noviny, 2017, 472 s. ISBN 9788074222702.
}

\section{DOI: https://doi.org/10.31577/histcaso.2019.67.2.10}

Pre životné záujmy Československa a Pol’ska, dvoch nástupníckych štátov utvorených po rozpade habsburskej monarchie, predstavovala Parížska mierová konferencia v roku 1919 klúčový význam. Komplikovaný proces politickej rekonštrukcie strednej Európy pod taktovkou dohodových vel'mocí si vyžadoval, aby súčast'ou delegácií účastníckych štátov boli aj početní odborníci z rôznych vedných odborov. Archivár a historik Masarykovho ústavu a Archivu Akademie věd Českej republiky Jan Chodějovský obohatil pramenné spektrum k problematike účasti vedcov na parížskych rokovaniach o edíciu ego-dokumentov. Publikovanie denníka Adolfa Černého doplneného o korešpondenciu Václava Viléma Štecha a Kazimierza Nitscha má podl'a zámeru editora napomôct' pri skúmaní procesu formovania politických rozhodnutí a mechanizmu samotných rokovaní z pohl'adu účastníkov, ktorí pôsobili v zákulisí „vel'kých“ politických dejín. Pridanou hodnotou sú dobové svedectvá týkajúce sa bežného života odborných poradcov československej a pol'skej delegácie a spoločenskej atmosféry panujúcej v centre svetovej diplomacie. Na výbere textov, tvorbe medailónov a spracovaní poznámok k súboru listov pol'ského jazykovedca K. Nitscha s manželkou Anielou Gruszeckou sa podiel'ali pracovníci krakovskej inštitúcie Archiwum Nauki Polskiej Akademii Nauk i Polskiej Akademii Umiejętności Tomasz Skrzyński a Marcin Maciuk. Pol’ský jazykový variant obsahuje aj edičná poznámka a biografické portréty pôvodcov dokumentov.

V úvode edičnej poznámky J. Chodějovský oboznámil čitatel'ov s prehl'adom memoárovej literatúry, odborných prác, edícií dokumentov úradnej i osobnej povahy a osob- 
ných fondov (s dôrazom na českú a pol'skú provenienciu), v ktorých sa vyskytuje tematika pôsobenia vládnych expertov na parížskych mierových rokovaniach. Editori boli nútení uverejnit' korešpondenciu v samostatných oddieloch podl'a odosielatel'ov. Spájat' listy s odpoved’ami chronologicky a podl'a obsahovej súvislosti totiž nebolo možné v dôsledku chaoticky fungujúcich poštových služieb po vojne. Ich ciel'om bolo zachovat' čo najväčšiu autentickost' dobových dokumentov s minimálnymi gramatickými a pravopisnými zásahmi. Vedecké a publicistické príspevky zmieňované v denníku a oboch súboroch listov sú v poznámkach pod čiarou opatrené bibliografickými údajmi. Editor mohol v poznámkach upozornit' aj na archívne uloženie expertných prác J. Černého, ktoré je možné identifikovat' $\mathrm{v}$ jeho denníkových zápiskoch. Zoznam Černého parížskych elaborátov s ich datovaním a uložením tvorí súčast' monografie Zdeňka Váchu Žádám Vás jako vynikajícího odborníka... (Praha 2013).

Rukopis „parížskeho“ denníka Adolfa Černého obsahuje záznamy od 6. januára 1919, ked’ z Prahy odcestovala prvá čast’ čs. delegácie, po 12. september, deň oficiálnej rozlúčky pred odchodom z francúzskej metropoly. Slavista Černý venoval v denníku najviac priestoru problematike Lužických Srbov, ktorá predstavovala hlavný predmet jeho odborných aktivít. Zaoberal sa nielen vypracúvaním memoránd a novinových článkov pre potreby československej delegácie, ale do činnosti lužickosrbského národného hnutia aj aktívne zasahoval (súčast'ou denníkových záznamov sú aj prepisy korešpondencie $\mathrm{s}$ ich vedúcimi predstavitel'mi). Rozhodujúce postavenie Edvarda Beneša v rámci delegácie je zretel'né z Černého poznámok z priebehu schôdzí, na ktorých minister zahraničia referoval o vlastnej diplomatickej taktike a obsahu vystúpení pred dohodovými politikmi. Problematiky Slovenska a Slovákov sa Černý dotkol v súvislosti s politickými činitel'mi pôsobiacimi v Paríži a s československo-pol'ským územným sporom o Oravu a Spiš, ktorý tvoril integrálnu súčast’ riešenia tešínskeho konfliktu. Okrem generálneho tajomníka delegácie Štefana Osuského, ktorý Černému vypomáhal pri presadzovaní lužickej agendy v diplomatických kruhoch a tlači, je v denníku venovaný väčší priestor ministrovi vojny ČSR. Denníkové zápisky poznačené charizmou osobnosti Milana Rastislava Štefánika rozširujú pramene osobnej povahy, aké zanechali d’alší „očareni“ členovia československej delegácie (Karel Kramáŕ, Hanuš Jelínek, nie však Rudolf Kalhous či Beneš). V denníku sú zaznamenané aj Černého dojmy zo stretnutí s viacerými osobnost'ami spätými s československým zápasom za nezávislost', napr. s historikom Ernestom Denisom a diplomatom Julesom Cambonom.

Druhý oddiel edície tvorí súbor 36 listov, ktoré si navzájom písali historik a teoretik umenia Václav Vilém Štech s manželkou Alexandrou za obdobie 4. marec - 7. jún 1919. Václav V. Štech, člen múzejnej sekcie ministerstva školstva, bol povolaný do poradného zboru československej delegácie $\mathrm{k}$ problematike reštitučných nárokov vzt’ahujúcich sa na kultúrne pamiatky. Ked’že táto oblast' bola primárne spojená s procesom uzatvárania mierovej zmluvy s Rakúskom, nemal tento vynikajúci znalec starej Prahy počas jarných mesiacov mnoho pracovných povinností. Zo skratkovitých poznámok k činnosti československej delegácie zaujmú postrehy o malej vzájomnej prepojenosti jednotlivých jej členov a obrovskej pracovnej vyt’aženosti Edvarda Beneša. Václav V. Štech v listoch zaznamenal aj napätie medzi členmi predvojnovej českej kolónie a l'ud’mi spojenými s Benešovou odbojovou činnost'ou. Každodenný život odborných poradcov zväčša pre- 
biehal v uzavretom mikrosvete hotela Lutetia. Ako vnímavý pozorovatel' parížskeho spoločenského života a umeleckej scény Štech registroval (po prvotnom očarení) nedostatok spoločnej viery v budúcnost', prameniacej z ničivých následkov vojny, finančnú vyčerpanost' krajiny, anarchistické tendencie v umení. Značná čast' vzájomnej korešpondencie s manželkou je venovaná praktickým existenčným záležitostiam (zásielky nedostatkového tovaru do Prahy a poštových známok určených na predaj do Paríža).

Editovaná korešpondencia profesora Jagelovskej univerzity Kazimierza Ignacyho Nitscha s manželkouAnielou Gruszeckou-Nitschowou je datovaná 5. februárom až 11. májom 1919. V častiach korešpondencie venovaných neprivátnym záležitostiam sa K. Nitsch, expert pre jazykové a etnografické otázky, zaoberal predovšetkým fungovaním pol'skej Kancelárie kongresových záležitostí v Paríži. Všímal si odlišný prístup jednotlivých dohodových štátov $\mathrm{k}$ pol'ským územným nárokom aj rôzne názorové prúdy $\mathrm{k}$ tejto problematike panujúce $\mathrm{v}$ pol'skej delegácii. Nitsch mal rezervovaný postoj k projektu „vel'kého Pol'ska“, ktorý presadzoval vedúci delegát Roman Dmowski. Okrem prednášok pre odbornú verejnost’ a písania memoránd (napr. o etnograficko-geografických pomeroch na Orave a Spiši) nadväzoval v meste nad Seinou vedecké kontakty, ktoré mali napomôct' pri presadzovaní pol'ských záujmov. Spisovatel'ka Aniela Nitschowá bola pri politicko-spoločenských témach, rozoberaných v korešpondencii, manželovi rovnocenným partnerom. V listoch odosielaných z Krakova - strediska pol’ských snáh o integráciu Oravy a Spiša - prezentovala poprevratové udalosti na týchto územiach ako mocenský zápas Čechov o ovládnutie pol’ského l’udu. V Nitschových úvahách týkajúcich sa mierového kongresu môžeme nájst' niekol'ko styčných miest, ktoré ho spájali s jeho československými náprotivkami. Podobne ako Adolf Černý sa zaoberal citlivou otázkou pracovnej etiky vedca zapojeného do politických služieb. Černý kritizoval členov československej delegácie za vypracovanie mapy Tešínskeho Sliezska skresl'ujúcej etnografické pomery na tomto spornom území. Nitsch zasa riešil dilemu ako skĺbit' vyhotovenie mapy pol'ských dialektov s oficiálnymi požiadavkami na východné hranice štátu. Obaja od vedúcich predstavitel'ov dohodových vel'mocí očakávali prirodzené pochopenie pre územné nároky Pol'ska, resp. Československa. (A pri oboch môžeme sledovat' skorú stratu počiatočného optimizmu). Nitsch aj Václav V. Štech kritizovali skorumpovanost' francúzskej tlače, ktorá poškodzovala záujmy práve ich domovských krajín. Svoje parížske pôsobenie pocit’ovali ako nevyužitie ich profesionálnych schopností.

Výberová bibliografia k činnosti delegácií jednotlivých štátov na parížskej konferencii obsahuje memoárovú literatúru, edície prameňov osobnej a úradnej povahy, ako aj štúdie publikované po roku 1970, ked' vyšiel rozsiahly súpis literatúry k tejto problematike od Maxa Gunzenhäusera. Zo slovenských autorov sú okrem člena expertnej časti čs. delegácie Fedora Houdeka zaznamenané práce siedmich historikov (v prípade Mariána Hronského je uvedená monografia Boj o Slovensko a Trianon 1918 - 1920 namiesto novšej a komplexnejšie poňatej publikácie Trianon. Vznik hraníc Slovenska a problémy jeho bezpečnosti 1918 - 1920 z roku 2011). Menný register obsahuje stručné biogramy všetkých osôb uvedených v tejto precízne pripravenej edícii.

Erik Dulovič

Štátny archív v Košiciach 